\title{
PEMBELAJARAN PENDIDIKAN MULTIKEAKSARAAN DENGAN TEMA KESEHATAN DAN OLAH RAGA PADA KOMUNITAS SUKU DAYAK
}

\author{
Nunung Nurazizah \\ e-mail: nunungnurazizah@yahoo.co.id \\ BP-PAUD dan Dikmas Kalimantan Selatan
}

\begin{abstract}
Abstrak: Penyelenggaraan pendidikan multikeaksaraan di komunitas suku Dayak masih belum sesuai dengan Peraturan Menteri Pendidikan dan Kebudayaan Republik Indonesia nomor 42 tahun 2015. Tujuan penelitian yaitu mengembangkan silabus dan bahan ajar pada pembelajaran pendidikan multikeaksaraan dengan sasaran komunitas adat suku dayak. Metode penelitian dengan reseach and development. Waktu penelitian dari Agustus sampai Oktober 2016. Tempat penelitian yaitu PKBM Bintang Timur Kabupaten Barito Utara dan PKBM Mawar Merah Kabupaten Kapuas. Hasil penelitian menunjukkan jika bahan ajar pendidikan multikeaksaraan berguna sebagai alat bantu bagi tutor untuk membelajarkan materi pendidikan multikeaksaraan yang sesuai dengan kurikulum, dan sebagai alat bantu bagi peserta didik untuk menguasai pesan/ materi pembelajaran yang disampaikan oleh tutor. Dampak dari penerapan silabus dan bahan ajar ini agar peserta didik dapat meningkatkan kemampuan keberaksaraannya dan adanya perubahan perilaku terampil menjaga kesehatan lingkungan.
\end{abstract}

Kata-kata kunci: bahan ajar, multikeaksaraan, Suku Dayak

\section{STUDY OF MULTI-LITERACY EDUCATION WITH HEALTH AND FIT- NESS THEMES ON ETHNIC DAYAK COMMUNITY}

\begin{abstract}
Implementation of multi-literacy education in Dayak ethnic community is still not accordance with the Regulation of the Minister of Education and Culture of Republic of Indonesia number 42 in 2015. The objective of this research is to develop a syllabus and learning materials on multi-literacy learning toward Dayak indigenous community as a target. Research methods used are research and development. The research was conducted from August to October 2016. It was also conducted in PKBM Bintang Timur Kabupaten Barito Utara and PKBM Mawar Merah Kabupaten Kapuas. Results show that multi-literacy learning materials are useful for tutors to deliver multi-literacy educational materials in accordance with a curriculum, and as a tool for learners to master the materials delivered by tutors. It is expected that the impact of the syllabus and learning materials implementation can escalate learners' multi-literacy abilities and behavior changes in maintaining environment.
\end{abstract}

Keywords: teaching materials, multicultural, Dayak ethnic

\section{PENDAHULUAN}

Layanan pendidikan keaksaraan memegang peran strategis dan penting dalam meningkatkan kualitas kehidupan masyarakat khususnya penduduk buta huruf. Program layanan pendidikan keaksaraan diharapkan dapat menurunkan angka buta aksara di Indonesia. Berdasarkan data Pusat Data dan Statistik Pendidikan Kementerian Pendidikan dan Kebudayaan pada tahun 2014 secara nasional masih terdapat sebesar $3,70 \%$ atau 5.984 .075 penduduk usia 15-59 tahun buta aksara sedangkan tingkat buta aksara untuk di Provinsi Kalimantan Tengah berdasarkan data Badan Pusat Statistik (BPS) Provinsi Kalimantan Tengah tahun 2014, penduduk laki-laki usia 10 tahun ke atas (pedesaan dan perkotaan) sebanyak 99,44\% memiliki kemampuan baca tulis dan $0,56 \%$ buta huruf; untuk penduduk perempuan usia 10 tahun ke atas (pedesaan dan perkotaan) memiliki kemampuan baca tulis sebanyak $98,31 \%$ dan $1,69 \%$ buta huruf. Berdasarkan data BPS Provinsi Kalimantan Tengah tahun 2014 tersebut, jumlah penduduk buta huruf di Kabupaten Barito Utara menempati urutan ke tiga di Provinsi 
Kalimantan Tengah, dengan data penduduk laki-laki 10 tahun ke atas kemampuan baca tulis (pedesaan dan perkotaan) sebanyak $99,18 \%(0,82 \%$ buta huruf) sedangkan penduduk perempuan 10 tahun ke atas kemampuan baca tulis (pedesaan dan perkotaan) sebanyak $97,86 \%$ (2,14\% buta huruf). Berdasarkan data lulusan penduduk lulus SD laki-laki $34,24 \%$ dan perempuan $31,23 \%$, lulus SMP laki-laki $18,16 \%$ dan perempuan $16,18 \%$, lulus SMA laki-laki $17,59 \%$ dan perempuan $12,48 \%$. Berdasarkan data statistik tersebut dapat disimpulkan bahwa di daerah Kabupaten Barito Utara masih diperlukan adanya pendidikan keaksaraan.

Di Kalimantan Tengah terdapat komunitas suku Dayak. Komunitas suku Dayak tersebut terdiri dari suku Dayak Ngaju, Dayak Siang, Dayak Dusun Malang, Dayak Lawangan, Dayak Tawoyan juga Dayak Bakumpai dan lainnya. Menurut Juknis penyelenggaraan Pendidikan Keaksaraan Dasar komunitas adat terpencil di Kalimantan Tengah terdapat tiga kabupaten prioritas yaitu Kabupaten Barito Utara, Kabupaten Murung Raya dan Kabupaten Barito Timur.

Pada tiga kabupaten tersebut pernah dilaksanakan Pendidikan Keaksaraan Dasar. Jika dilihat dari latar belakang pekerjaan masyarakat, penduduk memiliki pekerjaan seperti menjadi petani karet, nelayan tradisional, penambang emas, penambang pasir, penjual makanan, dan pekerjaan domestik lainnya. Berdasarkan hasil studi eksplorasi, penduduk memerlukan pendidikan keaksaraan lanjutan yang dapat membantu masyarakat meningkatkan keberagaman keberaksaraan dalam segala aspek kehidupan tidak sekedar meningkatkan kemampuan usaha. Oleh karena itu, lebih diarahkan kepada pendidikan multikeaksaraan.

Penyelenggaraan Pendidikan Multikeaksaraan yang sesuai dengan Peraturan Menteri Pendidikan dan Kebudayaan Republik Indonesia nomor 42 tahun 2015 belum dilaksanakan di kabupaten tempat studi pendahuluan dilakukan yaitu di Kabupaten Barito Utara, Kabupaten Murung Raya dan Palangkaraya. Berdasarkan wawancara dengan beberapa pengelola program pendidikan keaksaraan di tempat studi pendahuluan menuturkan bahwa pengelola mengalami kesulitan dalam melaksanakan program lanjutan pendidikan keaksaraan dasar karena belum memahami tentang pendidikan multikeaksaraan dan tidak ada perangkat program seperti silabus dan bahan ajar untuk program pendidikan multikeaksaraan. Oleh karena itu, perlu upaya memudahkan pengelola program dalam menyelenggarakan pendidikan multikeaksaraan yang sesuai dengan kurikulum pendidikan keaksaraan lanjutan.

Salah satu pendukung agar pelaksanaan pendidikan multikeaksaraan sesuai dengan kurikulum adalah ketersediaan silabus dan bahan ajar yang mengacu pada kurikulum pendidikan multikeaksaraan. Adanya silabus dan bahan ajar yang tepat diharapkan mampu memberikan pengetahuan, keterampilan sesuai dengan standar kompetensi yang diharapkan, karena pendidikan multikeaksaraan dirancang untuk keberaksaraan yang beragam maka keberagaman masyarakat sasaran program pendidikan multikeaksaraan sebaiknya terdapat dalam silabus dan bahan ajar yang digunakan. Selain untuk memberi kemudahan agar tidak lepas dari keseharian masyarakat yang menjadi sasaran.

Teori Pembelajaran Pendidikan Multikeaksaraan Pendidikan multikeaksaraan adalah pendidikan yang menekankan pada peningkatan keragaman keberaksaraan dalam segala aspek kehidupan. Program pendidikan multikeaksaraan merupakan program keaksaraan dengan menggunakan berbagai pendekatan (seni, budaya, lingkungan, teknologi, ras, etnis, gender, dan lainnya) yang relevan dengan kondisi peserta didik untuk mencapai dan atau mengembangkan kompetensi keberaksaraan serta meningkatkan penghasilan dan kualitas hidup peserta didik.

Tujuan pendidikan multikeaksaraan sesuai dengan Peraturan Menteri Pendidikan dan Kebudayaan Republik Indonesia nomor 42 tahun 2015 tentang Penyelenggaraan Pendidikan Keaksaraan Lanjutan, Pasal 2 "Penyelenggaraan pendidikan keaksaraan lanjutan bertujuan untuk mengembangkan potensi keaksaraan bagi warga masyarakat pasca pendidikan keaksaraan dasar". Standar Kompetensi Lulusan Pendidikan Multikeaksaraan Dasar sesuai Permendikbud nomor 42 tahun 2015 tentang penyelenggaraan pendidikan keaksaraan lanjutan pasal 4 meliputi kompetensi sikap, pengetahuan, dan keterampilan berupa (1) memiliki perilaku dan etika yang mencerminkan sikap orang beriman dan bertanggung jawab menjalankan peran dan fungsi dalam kemandirian berkarya di masyarakat untuk meningkatkan kualitas hidup; (2) menguasai pengetahuan faktual, konseptual, 
dan prosedural tentang pengembangan peran dan fungsi dalam kehidupan di masyarakat dengan cara berkomunikasi dalam bahasa Indonesia dan berhitung untuk meningkatkan kualitas hidup; serta (3) memiliki kemampuan menggunakan bahasa Indonesia dan keterampilan berhitung secara efektif dalam melakukan pengembangan peran dan fungsi untuk kemandirian berkarya di masyarakat serta meningkatkan kualitas hidup.

Kurikulum pendidikan multikeaksaraan terdiri atas kompetensi inti dan kompetensi dasar yang mencakup ranah sikap, pengetahuan, dan keterampilan dengan jumlah jam pelajaran minimal 86 Jam Pelajaran dengan satu jam pelajaran berdurasi 60 menit. Kompetensi dasar pendidikan multikeaksaraan pada dimensi sikap meliputi (1) meningkatkan rasa syukur dan keimanan kepada Tuhan Yang Maha Esa atas potensi diri yang dimiliki, (2) menunjukkan sikap jujur sebagai dasar dalam membangun hubungan sosial, serta (3) menunjukkan komitmen untuk membangun kebersamaan dalam mengembangkan peran dan fungsi dalam kehidupan di masyarakat.

Kompetensi dasar pendidikan multikeaksaraan pada dimensi pengetahuan meliputi (1) menggali informasi dari teks penjelasan tentang wawasan keilmuan dan teknologi, kesehatan dan olahraga, seni, budaya atau politik dan kebangsaan sesuai dengan yang diminati minimal tujuh kalimat sederhana; (2) menggali informasi dari teks penjelasan tentang profesi, atau kemahiran yang dimiliki dan diminati dalam tujuh kalimat sederhana; (3) menggali informasi dari teks khusus yang berbentuk brosur atau leaflet sederhana tentang teknologi, kesehatan dan olahraga, seni, budaya, politik, dan kebangsaan tertentu yang diminati berkaitan dengan pekerjaan atau profesinya; (4) mengenal penggunaan operasi bilangan tentang produk teknologi, kesehatan dan olahraga, seni, budaya atau jasa, dan uang yang disesuaikan dengan kebutuhan; (5) menggunakan konsep pecahan sederhana dalam melakukan penjumlahan dan pengurangan pada kehidupan sehari-hari; (6) menggali informasi dari teks tabel atau diagram sederhana yang berkaitan dengan kajian ilmu pengetahuan dan teknologi, kesehatan dan olahraga, seni, budaya, politik dan kebangsaan tertentu yang diminati; (7) mengidentifikasi pengetahuan keruangan (geometri) sederhana yang diterapkan dalam kajian keilmuan dan teknologi, kesehatan dan olahraga, seni, budaya, politik dan kebangsaan tertentu yang diminati dan digunakan dalam kehidupan sehari-hari; (8) menggali informasi dan teks petunjuk atau arahan yang berkaitan dengan pekerjaan, profesi atau kemahiran yang dimiliki dan diminati minimal tujuh kalimat sederhana; (9) menggali informasi dari teks narasi yang berkaitan dengan pekerjaan, profesi atau kemahiran yang dimiliki dan diminati minimal tujuh kalimat sederhana; serta (10) menggali informasi dari teks laporan yang berkaitan dengan pekerjaan, profesi atau kemahiran yang dimiliki dan diminati minimal tujuh kalimat sederhana.

Kompetensi dasar pendidikan multikeaksaraan pada dimensi keterampilan meliputi (1) mengolah informasi dari teks penjelasan tentang pekerjaan, profesi, atau kemahiran yang dimiliki dan diminati dalam bahasa Indonesia minimal lima kalimat sederhana secara lisan dan tertulis; (2) mengolah teks penjelasan tentang wawasan ilmu dan teknologi, kesehatan dan olahraga, seni, budaya, politik dan kebangsaan serta keterampilan tertentu dalam bahasa Indonesia minimal lima kalimat sederhana; (3) mengolah teks khusus yang berbentuk brosur atau leaflet sederhana tentang ilmu dan teknologi, kesehatan dan olahraga, seni, budaya, politik dan kebangsaan tertentu yang diminati berkaitan dengan pekerjaan atau profesinya; (4) mempraktikkan pengetahuan dan kreativitas yang dimiliki dan diminati menjadi produk teknologi sederhana, kesehatan dan olahraga, seni dan budaya yang inovatif dengan memanfaatkan peluang dan sumber daya yang ada di sekitarnya; (5) menggunakan sifat operasi hitung dalam menyederhanakan atau menentukan hasil penjumlahan, pengurangan, perkalian dan pembagian bilangan; (6) menggunakan uang atau jenis transaksi lainnya dalam kehidupan sehari-hari; (7) memperkirakan kebutuhan komponen produk teknologi, kesehatan dan olahraga, seni, budaya yang inovatif yang sedang dikerjakan, dimiliki dan diminati untuk menentukan biaya yang diperlukan; (8) menerapkan pecahan sederhana ke bentuk pecahan desimal dan persen pada hitungan yang berkaitan dengan uang dan produk teknologi sederhana, kesehatan dan olahraga, seni dan budaya yang inovatif dan diminati; (9) menggunakan satuan pengukuran, panjang, waktu, berat, atau satuan lainnya yang diperlukan pada kegiatan menciptakan produk teknologi sederhana, kesehatan dan olahraga, seni dan budaya yang inovatif; (10) 
menggunakan hasil pengolahan dan penafsiran data dalam bentuk tabel, diagram dan grafik sederhana mengenai kajian ilmu dan teknologi, kesehatan dan olahraga, seni, budaya, politik dan kebangsaan serta keterampilan tertentu yang diminati; (11) mengolah informasi dari tek narasi yang berkaitan dengan pekerjaan, profesi, atau kemahiran yang dimiliki dan diminati dalam lima kalimat sederhana secara lisan dan tertulis; (12) mempraktikkan kemitraan dalam mengembangkan produk teknologi sederhana, kesehatan dan olahraga, seni, budaya, secara inovatif yang diminati di wilayahnya; (13) mengolah informasi teks laporan yang berkaitan dengan hasil produk teknologi sederhana, kesehatan dan olahraga, seni, budaya, secara inovatif yang diminati; serta (14) mengkomunikasikan ide dan produk inovatif berkaitan dengan ilmu dan teknologi, kesehatan dan olahraga, seni, budaya, yang diminati. Teori Pengembangan Silabus dan Bahan Ajar

Silabus merupakan garis besar pembelajaran untuk satu semester/satu tahun/satu penyelenggaraan program. Silabus berisi rencana pembelajaran pada suatu kelompok mata pelajaran/tema tertentu yang mencakup standar kompetensi, kompetensi dasar, materi pokok/pembelajaran, kegiatan pembelajaran, indikator penilaian, alokasi waktu, sistem penilaian, dan sumber/bahan/alat belajar .

Manfaat silabus adalah sebagai pedoman sumber pokok dalam pengembangan pembelajaran lebih lanjut mulai dari pembuatan rencana pembelajaran, pengelolaan kegiatan pembelajaran, dan pengembangan sistem penilaian. Silabus disusun berdasarkan kurikulum program yang akan dilaksanakan baik kurikulum nasional atau yang disusun sendiri.

Prinsip-prinsip pengembangan silabus adalah (1) ilmiah, artinya keseluruhan materi dan kegiatan yang menjadi muatan dalam silabus harus benar dan dapat dipertanggungjawabkan; (2) relevan, artinya cakupan, kedalaman, tingkat kesukaran dan urutan penyajian materi dalam silabus sesuai dengan tingkat pencapaian fisik, intelektual, sosial, emosional dan spiritual peserta didik; (3) sistematis, artinya komponen-komponen silabus saling berhubungan secara fungsional dalam mencapai kompetensi; (4) konsisten, artinya adanya hubungan yang konsisten (ajeg, taat asas) antara kompetensi dasar, indikator, materi pokok, pengalaman belajar, sumber belajar, dan sistem penilaian; (5) memadai, artinya cakupan indikator, materi pokok, pengalaman belajar, sumber belajar dan sistem penilaian cukup untuk menunjang pencapaian kompetensi dasar; (6) aktual dan kontekstual, artinya cakupan indikator, materi pokok, pengalaman belajar, sumber belajar, dan sistem penilaian memperhatikan perkembangan ilmu, teknologi, dan seni mutakhir dalam kehidupan nyata, dan peristiwa yang terjadi; (7) fleksibel, artinya keseluruhan komponen dapat mengakomodasi keragaman peserta dan pendidik, serta dinamika perubahan yang terjadi di sekolah dan tuntutan masyarakat; serta (8) menyeluruh, artinya komponen silabus mencakup keseluruhan ranah (kognitif, afektif, dan psikomotor). Pengembangan silabus multikeaksaraan, memperhatikan beberapa hal, yaitu (1) kondisi, kebutuhan, kapasitas dan karakteristik kelompok belajar dan masyarakatnya; (2) memilih salah satu atau beberapa materi dan tema pembelajaran yang berkaitan dengan keilmuan dan teknologi, kesehatan dan olahraga, seni budaya, atau politik dan kebangsaan, serta pekerjaan/profesi yang disesuaikan dengan minat dan kebutuhan peserta didik.

Langkah-langkah pengembangan silabus adalah (1) memetakan kompetensi pendidikan multikeaksaraan; (2) mengidentifikasi tema pembelajaran berdasarkan kurikulum dan potensi serta permasalahan pada kelompok sasaran; (3) memilih dan menetapkan tema/subtema sesuai karakteristik dan kebutuhan kelompok belajar; (4) memilih kompetensi inti, kompetensi dasar, dan indikator pencapaian kompetensi; (5) memilih dan menetapkan materi pembelajaran; (6) merumuskan kegiatan pembelajaran untuk mencapai kompetensi yang diharapkan dengan memperhatikan peserta didik, kelompok belajar, sumber belajar, dan sumber daya yang tersedia sesuai dengan tema yang dipilih, kebutuhan dan karakteristik pembelajaran; (7) alokasi waktu disesuaikan dengan kesediaan dan kebutuhan peserta didik, dengan total alokasi waktu sesuai Permendikbud nomor 4 tahun 2015 yaitu 86 jam pelajaran; (8) merumuskan garis besar penilaian; serta (9) sumber belajar meliputi alat, media, sarana pembelajaran, bahan ajar, dan sumber belajar lainnya. Bahan ajar selanjutnya akan dikembangkan sesuai kurikulum dan silabus hasil pengembangan ini serta menjadi bagian dalam pengembangan model.

Bahan ajar merupakan media agar peserta didik dapat mengalami, menghayati, mengolah, mengungkapkan, menyimpulkan dan menerapkan materi-materi yang telah diajarkan dalam kehidupan 
sehari-hari, juga segala bentuk bahan yang digunakan untuk membantu tutor dalam melaksanakan kegiatan belajar mengajar. Bahan belajar yang baik dalam pendidikan keaksaraan perlu memenuhi beberapa persyaratan, yaitu (1) membangkitkan motivasi belajar peserta didik, (2) relevan dengan lingkungan dan kehidupan peserta didik, serta (3) fungsional dan langsung bermanfaat dalam kehidupan sehari-hari peserta didik.

Secara umum, jenis bahan ajar biasanya terdiri atas handout, buku, modul, dan belajar terprogram. Dalam pendidikan multikeaksaraan yang dimaksud dengan bahan ajar adalah isi pesan yang menjadi materi belajar baik tulisan atau gambar yang dituangkan dalam media tertentu misalnya dalam bentuk buku, poster, leaflet, dan sebagainya yang dapat digunakan oleh peserta didik. Bentuk bahan belajar pendidikan multikeaksaraan terdiri dari (1) tulisan seperti buku, brosur, leaflet dan lain-lain; (2) gambar, seperti poster, film, video dan lain-lain; (3) alat peraga, yaitu benda wujud nyata, seperti alat dan bahan praktik; serta 4) gabungan (kombinasi) tulisan, gambar, alat peraga, seperti buku bergambar, alat, dan bahan praktik.

Kegunaan bahan ajar dalam pendidikan multikeaksaraan adalah (1) sebagai alat bantu bagi tutor untuk membelajarkan materi pendidikan multikeaksaraan yang sesuai dengan kurikulum dan (2) sebagai alat bantu bagi peserta didik untuk menguasai pesan/ materi pembelajaran yang disampaikan oleh tutor. Bahan ajar pendidikan multikeaksaraan dikembangkan dengan maksud (1) memperkuat kemampuan keaksaraan peserta didik; (2) memberikan akses/kemudahan peserta didik dalam memperoleh informasi; (3) mengembangkan kesadaran kritis peserta didik; (4) membentuk sikap mental rasional/logis, dan ilmiah peserta didik; (5) berorientasi pada nilai, sikap mental, dan keterampilan yang diinginkan; serta (6) memberikan hiburan pada peserta didik.

Jadi, bahan ajar multikeaksaraan dalam penelitian ini adalah media yang digunakan oleh tutor dan peserta didik dalam pembelajaran multikeaksaraan yang disesuaikan dengan budaya lokal masyarakat adat terpencil dengan menggunakan pendekatan bahasa ibu (bahasa Dayak).

\section{Teori Komunitas Suku Dayak}

Pengertian "Suku Dayak" secara epistemologi identik dengan para penduduk pedalaman Pulau Kalimantan. Kata Dayak merupakan sebutan dari penduduk pesisir Borneo kepada para penduduk pedalaman yang tersebar di beberapa wilayah yaitu Indonesia (meliputi Kalimantan Timur, Kalimantan Tengah, Kalimantan Barat, dan Kalimantan Selatan), Brunei dan Malaysia. Pengertian lain menyebut Dayak sebagai orang yang tinggal di hulu sungai, sedangkan orang Dayak mengartikan Dayak sebagai karakteristik personal yang berarti kuat, gagah, berani, dan ulet. Dapat disimpulkan bahwa komunitas suku Dayak diartikan sebagai kelompok sosial yang berasal dari beberapa orang yang saling berinteraksi di daerah tertentu dan saling berbagi lingkungan karena adanya kesamaan tempat tinggal di daerah pedalaman atau hulu sungai.

Komunitas suku Dayak di Kalimantan memiliki berbagai komunitas. Komunitas tersebut sebagai subetnik dari rumpun suku Dayak itu sendiri. Kalimantan Tengah memiliki rumpun suku Dayak Ot Danum, Dayak Ngaju, Dayak Dusun Maanyan dan rumpun Dayak Lawangan. Adanya pengaruh suku luar yaitu Suku Melayu Banjar terhadap suku Dayak Ngaju, mengakibatkan munculnya anak suku bernama Dayak Bakumpai. Pengembangan pada penelitian ini lebih menitikberatkan pada komunitas mayoritas yaitu Dayak Ngaju dan Dayak Bakumpai dikarenakan kemiripan bahasa, sebagian Bahasa Dayak Bakumpai juga menggunakan Bahasa Dayak Ngaju.

\section{METODE PENELITIAN}

Penelitian ini bertujuan untuk mengembangkan silabus dan bahan ajar pada pembelajaran pendidikan multikeaksaraan dengan sasaran komunitas adat suku Dayak. Sesuai dengan tujuan penelitian ini, maka metode penelitian yang digunakan adalah metode penelitian pengembangan (reseach and development). Metode penelitian pengembangan adalah metode penelitian yang digunakan untuk menghasilkan produk tertentu dan menguji keefektifan produk. Pengertian tersebut sesuai dengan tujuan pengembangan model ini yaitu untuk menghasilkan produk berupa bahan ajar, oleh karena itu, metode yang digunakan adalah metode penelitian pengembangan oleh Borg and Gall.

Menurut Borg dan Gall (1979), prosedur pengembangan disesuaikan dengan kebutuhan 
secara konseptual.

Penelitian ini mengikuti beberapa langkah, yaitu pertama, identifikasi kebutuhan pengembangan dilakukan melalui studi lapangan dan studi kepustakaan.

Kedua, pengembangan model konseptual meliputi penyusunan draf model, FGD draf model untuk mendapatkan masukan perbaikan, revisi dan validasi draf model oleh akademisi atau teman sejawat dan peserta FGD, uji coba konseptual yang dilakukan dengan melibatkan pakar, praktisi, profesional pada bidang yang sesuai dengan model yang sedang dikembangkan serta kepada calon penguna model (tutor program pendidikan multikeaksaraan), review model konseptual yang dilakukan dengan melibatkan tim pengembang, serta akademisi/ pakar/ praktisi yang membidangi untuk memperoleh perbaikan model konseptual.

Ketiga, uji coba model operasional, tahap ini digunakan untuk menguji keefektifan hasil pengembangan model tersebut serta mengetahui kelebihan dan kelemahannya, dilakukan dengan langkah-langkah meliputi menetapkan rancangan uji coba pada dua kelompok yaitu kelas kontrol dan kelas treatment yang keduanya berada di wilayah/ kabupaten yang berbeda yaitu untuk kelas treatment pada Kabupaten Barito Utara dan kelas kontrol pada Kabupaten Kapuas dengan jumlah kelompok treatment 3 kelompok masing-masing 20 warga belajar, kegiatan orientasi calon sasaran uji coba pengembangan model guna menyamakan persepsi dan pemahaman calon sasaran uji coba terhadap model yang akan diujicobanya di lapangan, melaksanakan uji coba yang disertai dengan monitoring pelaksanaan uji coba dan analisis hasil uji coba menggunakan tes, wawancara, dan observasi sebagai tekniknya, serta melakukan review/ FGD hasil uji coba pengembangan model yang dilakukan untuk menyeminarkan hasil uji coba guna mendapat saran dalam perbaikan model sehingga menjadi satu naskah model final yang siap dibakukan dan selanjutnya digandakan.

Keempat, pembakuan model hasil pengembangan yang dilakukan melalui kegiatan diskusi dengan melibatkan unsur direktorat terkait untuk memperoleh masukan perbaikan dan pengesahan.

Uji coba dalam penelitian pengembangan ini dilakukan di PKBM Bintang Timur Kabupaten Barito Utara (sebagai kelompok treatment) dan PKBM Mawar Merah Kabupaten Kapuas (sebagai kelompok control). Subjek uji coba dalam penelitian ini adalah tutor dan peserta didik sebanyak 40 orang peserta didik pendidikan multikeaksaraan.

Teknik yang digunakan dalam penelitian pengembangan ini berupa tes, wawancara, observasi, menyebarkan kuesioner, dan dokumentasi. Teknik dokumentasi digunakan saat tahap studi pendahuluan. Teknik menyebarkan kuesioner digunakan saat uji coba konseptual model untuk mengetahui tingkat keterbacaan dan kemenarikan naskah model yang selanjutnya dianalisis menggunakan rata-rata (mean). Teknik tes digunakan untuk mengukur keberhasilan pembelajaran menggunakan naskah model pengembangan yang selanjutnya dianalisis menggunakan $t$-test untuk mengetahui tingkat efektivitas produk. Teknik wawancara untuk memperoleh informasi mendalam terkait penggunaan produk yang dikembangkan dan observasi untuk melihat keterpakaian model dan dampak model yang selanjutnya dianalisis secara induktif kualitatif. Selanjutnya, hasil analisis dan pembahasan digunakan sebagai bahan menyusun kesimpulan dan merumuskan saran penelitian.

\section{HASIL DAN PEMBAHASAN}

\section{Hasil}

Berdasarkan hasil studi pendahuluan dan mengacu pada standar kompetensi dan kompetensi dasar pendidikan multikeaksaraan, tema pembelajaran yang dikembangkan adalah kesehatan dan olah raga dengan sub tema kesehatan lingkungan. Pemilihan tema dan subtema tersebut berdasarkan kondisi di daerah sasaran pengembangan program yang memerlukan pembinaan terkait menjaga kesehatan lingkungan.

Berdasarkan tema dan subtema yang dipilih dan mengacu pada standar kompetensi dan kompetensi dasar pendidikan multikeaksaraan sesuai Permendikbud no. 42 tahun 2015, struktur kurikulum dan materi pembelajarannya seperti tertera pada Tabel 1. 
Tabel 1

\section{Struktur Kurikulum}

\begin{tabular}{lllll}
\hline No. & \multicolumn{1}{c}{ Materi } & \multicolumn{3}{c}{ Alokasi Waktu } \\
& & T & P & Jml \\
\hline 1. & $\begin{array}{l}\text { Kesehatan lingkungan rumah dan } \\
\text { sekitar }\end{array}$ & 2 & 6 & 8 \\
2. & Penyakit berbasis lingkungan & 2 & 4 & 6 \\
3. & Menghitung, tabel dan Geometri & 8 & 24 & 32 \\
4. & Makanan dan minuman sehat & 4 & 12 & 16 \\
5. & Pengolahan sampah/ limbah & 4 & 8 & 12 \\
6. & Pelaporan kegiatan/ usaha & 2 & 6 & 8 \\
7. & Kemitraan & 2 & 2 & 4 \\
& & 24 & 57 & 86 jam \\
\hline
\end{tabular}

Catatan: 1 jam pelajaran setara dengan 60 menit.

Dari struktur kurikulum tersebut dikembangkan silabus yang didesain berkonteks lokal suku Dayak yaitu dalam silabus menggunakan dua bahasa yaitu bahasa Indonesia dan bahasa Dayak. Berdasarkan struktur kurikulum, silabus, dan materi selanjutnya, bahan ajar disusun dalam tiga seri bahan ajar yaitu (1) Seri Kesehatan lingkungan rumah dan sekitar, (2) Seri Menghitung, serta (3) Seri Terampil menyehatkan lingkungan.

Uji validitas konseptual produk silabus dan bahan ajar pendidikan multikeaksaraan tema kesehatan dan olahraga sub tema kesehatan lingkungan diperoleh dengan perhitungan rata-rata (mean) dalam bentuk persentase. Hasil perhitungan tingkat validitas model konseptual diperoleh $83,8 \%$ yang berarti tingkat validitas sangat tinggi. Uji kemenarikan dan keterbacaan konseptual diperoleh dengan perhitungan rata-rata (mean) dan diperoleh hasil $77,4 \%$ yang berarti tingkat kemenarikan model dalam kategori tinggi.

Silabus dan bahan ajar diterapkan pada dua kelompok sasaran pada wilayah yang berbeda, namun memiliki karakteristik yang sama yaitu menggunakan bahasa sehari-hari yang sama yaitu bahasa Dayak Ngaju dan bahasa Dayak Bakumpai, memiliki kondisi lingkungan dan permasalahan yang sama yaitu masyarakat pinggiran sungai yang memanfaatkan aliran sungai untuk berbagai keperluan hidup sehari-hari termasuk untuk membuang sampah.

Penerapan silabus dan bahan ajar diawali dengan kegiatan pre-test atau penilaian awal dan dilanjutkan dengan kegiatan pembelajaran serta diakhiri dengan ujian dengan soal yang sama antara kedua kelompok. Aksi dalam kegiatan pembelajaran multikeaksaraan berupa praktik membuat jamu, pupuk kompos, tempat sampah dari drum bekas, kerajinan dari barang bekas, serta kemasan. Perancangan kegiatan atau aksi dalam pembelajaran melibatkan peserta didik berdasarkan minat dan kebutuhan peserta didik dengan memanfaatkan potensi setempat yang ada.

1. Analisis Kelas/ Uji Normalitas

Menggunakan uji normalitas kormogorov smirnov, dengan membandingkan distribusi data yang akan diuji normalitasnya.

Tabel 2

Hasil Uji Kolmogorov Smirnov

\begin{tabular}{lllll}
\hline & $\begin{array}{l}\text { Pre } \\
\text { Treat }\end{array}$ & $\begin{array}{l}\text { Pre } \\
\text { Control }\end{array}$ & $\begin{array}{l}\text { Post } \\
\text { Treat }\end{array}$ & $\begin{array}{l}\text { Post } \\
\text { Control }\end{array}$ \\
\hline Asymp sig (2-tailed) & 0,935 & 0,672 & 0,880 & 0,806 \\
\hline Distribusi data tes diperoleh signifikan diatas 0,05 & berarti data \\
yang diuji normal
\end{tabular}

2. Uji Efektivitas produk

Dilakukan melalui uji-t paired sample test. Uji ini digunakan untuk membandingkan selisih dua mean dari dua sampel berpasangan dengan asumsi distribusi normal seperti tertera pada Tabel 3.

Tabel 3

Uji-t Paired Sample Test

\begin{tabular}{|c|c|c|c|c|c|c|c|c|}
\hline & \multicolumn{5}{|c|}{ Paired Differences } & \multirow[t]{3}{*}{ t } & \multirow[t]{3}{*}{ df } & \multirow{3}{*}{$\begin{array}{l}\text { Sig. } \\
\text { (2-tailed) }\end{array}$} \\
\hline & \multirow[t]{2}{*}{ Mean } & \multirow[t]{2}{*}{$\begin{array}{l}\text { Std. De- } \\
\text { viation }\end{array}$} & \multirow[t]{2}{*}{$\begin{array}{l}\text { Std. Error } \\
\text { Mean }\end{array}$} & \multicolumn{2}{|c|}{$\begin{array}{l}95 \% \text { Confidence Interval } \\
\text { of the Difference }\end{array}$} & & & \\
\hline & & & & Lower & Upper & & & \\
\hline $\begin{array}{l}\text { Pair } 1 \\
\text { post_treat } \\
\text { - pre_treat }\end{array}$ & $2.59000 E 1$ & 8.37226 & 1.87209 & 21.98166 & 29.81834 & 13.835 & 19 & .000 \\
\hline
\end{tabular}

Menurut hipotesis dalam uji-t paired sample test, jika sig. $<0,05$ berarti ada perbedaan. Uji-t paired sample test menghasilkan signifikan 0,000. Berarti angka signifikan kurang dari 0,05. Hasil tersebut menunjukkan ada perbedaan antara kedua kelas yang diuji.

Dilanjutkan dengan uji-t Independent t-test diperoleh hasil 0,48 yang berarti ada perbedaan yang signifikan antara kelas treatment yang pembelajarannya menggunakan silabus dan bahan ajar hasil pengembangan dengan kelas kontrol sehingga silabus dan bahan ajar pendidikan multikeaksaraan yang bertema kesehatan dan olahraga, subtema kesehatan lingkungan yang digunakan dalam pembelajaran pendidikan multikeaksaraan berpengaruh terhadap efektivitas keberhasilan pembelajaran.

\section{Pembahasan}

Program pendidikan multikeaksaraan pada ranah pendidikan keaksaraan adalah program 
yang baru bagi sebagian masyarakat. Masyarakat lebih mengenal program pendidikan keaksaraan dasar/fungsional dan keaksaraan usaha mandiri. Adanya Peraturan Menteri Pendidikan dan Kebudayaan nomor 42 tahun 2015 tentang pedoman penyelenggaraan pendidikan keaksaraan lanjutan, memberikan landasan operasional dan penjelasan adanya program pendidikan multikeaksaraan dalam ranah pendidikan keaksaraan lanjutan.

Sebagai program yang baru dalam masyarakat, program pendidikan multikeaksaraan belum banyak dilaksanakan terutama pada komunitas suku Dayak. Guna mendukung terlaksananya program pendidikan multikeaksaraan, maka perlu adanya kelengkapan sarana pembelajaran berupa silabus dan bahan ajar yang dapat memberikan kemudahan bagi para penyelenggara dan pendidik program pendidikan multikeaksaraan yang didesain berkonteks lokal.

Pembahasan hasil kajian pembelajaran pendidikan multikeaksaraan dengan tema kesehatan dan olahraga pada komunitas suku Dayak ini difokuskan pada (1) produk pengembangan silabus dan bahan ajar pendidikan multikeaksaraan pada komunitas suku dayak, (2) penggunaan produk silabus dan bahan ajar dalam pembelajaran pendidikan multikeaksaraan, serta (3) efektifitas produk.

Produk pengembangan yang dihasilkan dalam penelitian pengembangan ini adalah berupa silabus dan bahan ajar pendidikan multikeaksaraan dengan tema kesehatan dan olahraga, subtema kesehatan lingkungan. Sesuai dengan tujuan dalam penelitian pengembangan ini melengkapi sarana pendukung penyelenggaraan program pendidikan multikeaksaraan dalam bentuk silabus dan bahan ajar yang didesain berkonteks lokal suku Dayak.

Berdasarkan Permendikbud Nomor 42 tahun 2015 pasal 9 diperoleh ketentuan kurikulum pada pendidikan keaksaraan lanjutan berupa program pembelajaran dengan pendekatan tematik terpadu yang fungsional yaitu terintegrasi dengan kehidupan keseharian peserta didik, meliputi agama, sosial, budaya, ekonomi, kesehatan, dan lingkungan. Oleh karena itu, ditetapkan tema kesehatan dan olahraga dan subtema kesehatan lingkungan karena kelompok sasaran lebih memerlukan pembinaan dan peningkatan bidang kesehatan lingkungan.

Silabus pembelajaran yang didesain konteks lokal sehingga dalam silabusnya menggunakan pendekatan bahasa ibu yaitu dalam bahasa Dayak
Ngaju dan bahasa Indonesia dengan materi pembelajaran dari permasalahan kesehatan lingkungan di kelompok sasaran komunitas suku Dayak, khususnya di Kabupaten Barito Utara dan Kabupaten Kapuas. Silabus yang dikembangkan sesuai dengan struktur kurikulum yang dikembangkan yaitu diperuntukkan 86 jam pelajaran.

Materi dalam bahan ajar mengacu pada Permendikbud Nomor 42 tahun 2015 dan disesuaikan dengan kebutuhan kelompok sasaran yang meliputi (a) teks penjelasan tentang kesehatan lingkungan seperti ciri-ciri rumah sehat dan pemanfaatan lingkungannya, penjelasan tentang pencemaran sungai dan udara yang terjadi di sekitar; (b) teks penjelasan tentang profesi pekerjaan atau kemahiran di bidang kesehatan lingkungan seperti pengelola sampah, pengolah dan penjual makanan, serta minuman kesehatan; (c) teks khusus berbentuk brosur tentang penyakit berbasis lingkungan dan promosi produk kesehatan lingkungan; (d) operasi hitung bilangan berkaitan dengan kesehatan lingkungan; e) pecahan sederhana yang digunakan dalam bidang kesehatan lingkungan; (f) teks tabel/diagram/grafik tentang produk atau masalah kesehatan lingkungan; (g) uang dan transaksi; (h) pengenalan geometri sederhana serta pengukuran panjang,waktu, berat atau satuan lainnya yang diterapkan dalam pekerjaan bidang kesehatan lingkungan; (i) teks narasi tentang pekerjaan, profesi atau kemahiran yang dimilki atau diminati terkait kesehatan lingkungan; (j) teks laporan tentang program atau usaha menjaga kesehatan lingkungan; (k) teks petunjuk tentang rancangan ide inovatif program atau produk meningkatkan kesehatan masyarakat; serta (I) kemitraan dalam mengembangkan produk inovatif program kesehatan masyarakat

Materi tersebut disusun dalam tiga seri bahan ajar. Materi disajikan dengan strategi transliterasi yaitu disajikan dalam tiga bahasa, yang meliputi (a) teks berwarna merah menggunakan bahasa Dayak Ngaju yaitu bahasa asli masyarakat Dayak yang digunakan dalam lingkup lebih luas se-provinsi, (b) teks berwarna hitam menggunakan bahasa Indonesia karena disesuaikan dengan standar kompetensi lulusan yaitu mampu berkomunikasi dalam bahasa Indonesia, (c) teks berwarna biru menggunakan bahasa Dayak Bakumpai yaitu bahasa Dayak dari sebagian anak suku Dayak karena terdapat banyak anak suku dengan ragam 
bahasa yang berbeda-beda dan Bakumpai adalah salah satunya sehingga merupakan bahasa yang digunakan pada kelompok sasaran uji coba.

Penggunaan produk silabus dan bahan ajar dipermudah dengan adanya panduan penggunaan silabus dan bahan ajar yang didalamnya memberikan kiat menyusun RPP dengan menggunakan silabus yang sudah dikembangkan serta langkah-langkah pembelajarannya pada setiap pertemuan sesuai dalam bahan ajar. Adanya silabus dan bahan ajar yang digunakan dalam pembelajaran pendidikan multikeaksaraan, maka tujuan penelitian pengembangan yaitu melengkapi sarana pembelajaran berupa silabus dan bahan ajar agar memudahkan pengelola dan pendidik program pendidikan multikeaksaraan tercapai. Pendidik khususnya memperoleh kemudahan dalam menyusun RPP sudah ada panduan dan acuannya tinggal menuliskan sesuai dalam silabus, panduan, dan bahan ajar. Bahkan media pembelajarannya pun digambarkan sehingga pendidik lebih mudah dalam mempraktikkan pembelajarannya khususnya materi-materi dalam seri berhitung. Selain itu, dalam penilaian proses pembelajarannya juga sudah tercantum dalam bahan ajar sehingga pendidik tidak kesusahan menyusun instrumennya.

Penggunaan bahan ajar dapat dilakukan dalam pembelajaran baik tatap muka, tutorial, dan pendampingan. Karena keterbatasan penyusunan bahan ajar, maka dalam pembelajaran materi dapat berkembang atau bertambah dari hasil pembelajaran dengan strategi belajar dari pengalaman sendiri (BDPS).

Respon peserta didik dapat diketahui dari wawancara dan pengamatan. Adanya bahan ajar membuat peserta didik dapat membaca dan mengulang kembali materi pembelajaran di rumah. Pengulangan dapat dilakukan bersama pendidik maupun orang lain (yang dikenal dengan sebutan tutor sebaya). Peserta didik dapat memanfaatkan meteri dalam bahan ajar untuk meningkatkan kualitas kehidupan sehari-hari khususnya memelihara kesehatan lingkungan dan pribadi. Contohnya untuk mengatasi penyakit tidak harus langsung ke dokter yang lokasinya jauh tetapi dapat dengan membuat ramuan obat dari tumbuh-tumbuhan obat di hutan sekitarnya. Peserta didik memiliki etika dan perilaku yang lebih baik dalam menangani sampah, misalnya membuang sampai pada tempat sampah bukan di sungai dan memanfaatkan sampah organik menjadi kompos.

Efektivitas produk dalam pembelajaran diketahui dengan membandingkan selisih dua mean dari sampel kelas eksperimen dan kontrol. Uji efektivitas ini mengunakan nilai hasil pre-test dan post-test kedua kelompok. Berdasarkan hasil pengujian diperoleh angka signifikan 0,048 yang menurut hipotesis jika angka signifikan $<0,05$ sehingga hipotesis nol ditolak. Artinya terdapat perbedaan hasil belajar peserta didik yang dibelajarkan menggunakan bahan ajar pendidikan multikeaksaraan tema kesehatan, subtema kesehatan lingkungan dengan yang tidak menggunakan. Hasil pengujian tersebut memberikan pengertian bahwa adanya produk penelitian pengembangan yang berupa bahan ajar pendidikan multikeaksaraan tema kesehatan, subtema kesehatan lingkungan yang digunakan dalam pembelajaran pendidikan multikeaksaraan pada komunitas suku Dayak ada pengaruhnya terhadap pencapaian hasil belajar peserta didik.

Melalui pengujian tersebut maka bahan ajar pendidikan multikeaksaraan tema kesehatan, subtema kesehatan lingkungan telah berhasil dan berguna sebagai alat bantu bagi tutor untuk membelajarkan materi pendidikan multikeaksaraan yang sesuai dengan kurikulum, dan sebagai alat bantu bagi peserta didik untuk menguasai pesan/ materi pembelajaran yang disampaikan oleh tutor.

Pembelajaran pendidikan multikeaksaraan tema kesehatan dan subtema kesehatan lingkungan pada komunitas suku Dayak telah efektif meningkatkan hasil belajar peserta didik baik ranah sikap, pengetahuan, maupun keterampilan. Dampak lain pembelajaran pendidikan multikeaksaraan tema kesehatan dan subtema kesehatan lingkungan pada komunitas suku Dayak selain pada ketercapaian kompetensi juga munculnya perubahan perilaku masyarakat dalam menjaga dan meningkatkan kesehatan lingkungan sekitarnya.

\section{PENUTUP}

\section{Kesimpulan}

Pendidikan multikeaksaraan adalah program pendidikan keaksaraan lanjutan yang menekankan peningkatan keragaman keberaksaraan dalam 
segala aspek kehidupan, meliputi keilmuan dan teknologi, kesehatan dan olahraga, seni, budaya, atau politik, dan kebangsaan. Sasaran program pendidikan multikeaksaraan adalah warga masyarakat yang sudah memiliki kemampuan keaksaraan dasar. Silabus dan bahan ajar pendidikan multikeaksaraan yang dikembangkan didesain lokal dengan memanfaatkan potensi, budaya, permasalahan, dan kondisi lingkungan sekitar sasaran program yang ditulis dalam tiga bahasa yaitu bahasa Dayak Ngaju, bahasa Indonesia, dan bahasa Dayak Bakumpai sehingga memudahkan peserta didik memahami materi pembelajaran dan bisa menerapkan isi materi dalam aspek kehidupan sehari-hari.

Berdasarkan hasil tes diketahui 10 peserta dari 20 peserta dari kelompok treatment dinyatakan lulus pendidikan multikeaksaraan karena nilainya di atas 56, dan untuk kelas kontrol diketahui lulus 6 orang dari 20 orang. Hal ini menunjukkan kemampuan keberaksaraan meningkat. Berdasarkan observasi terhadap perilaku keseharian peserta didik diketahui materi dalam pembelajaran pendidikan multikeaksaraan tema kesehatan dan olahraga memberi dampak terhadap perubahan perilaku dalam menjaga kebersihan lingkungan. Berdasarkan hasil wawancara dengan tutor, dinyatakan peserta didik memperoleh kemudahan dalam menyelenggarakan pendidikan multikeaksaraan.

\section{Saran}

Silabus dan bahan ajar merupakan bagian penting yang harus disiapkan sebelum menyelenggarakan suatu program pendidikan.
Silabus memudahkan tutor dalam merancang pembelajaran sedangkan bahan ajar memudahkan tutor dalam membelajarkan isi suatu program. Dengan bahan ajar yang sesuai dengan standar kurikulum akan menghantarkan peserta didik untuk mencapai standar kompetensi lulusan.

Menyiapkan silabus dan bahan ajar pada pendidikan multikeaksaraan merupakan salah satu kesulitan pengelola atau tutor pendidikan multikeaksaraan. Oleh karena itu, adanya pengembangan model silabus dan bahan ajar pendidikan multikeaksaraan pada komunitas suku Dayak diharapkan memudahkan pengelola dan tutor dalam menyelenggarakan program pendidikan multikeaksaraan.

Penyusunan silabus dan bahan ajar ini dilakukan sebagai upaya (1) dalam rangka pengembangan keilmuan dalam proses pelayanan kebutuhan belajar khususnya pada program pendidikan multikeaksaraan dengan tema kesehatan dan olahraga dapat dikembangkan subtema lain untuk mendukung peningkatan kesehatan masyarakat; (2) sasaran pendidikan multikeaksaraan berasal dari lulusan keaksaraan dasar yang belum terstandar maka pendidik hendaknya meningkatkan layanan tutorial agar pencapaian hasil belajar meningkat; serta (3) bagi para pengambil kebijakan agar dapat memfasilitasi aksi pemberdayaan dalam pembelajaran multikeaksaraan sehingga tidak sebatas pencapaian kompetensi namun pada perbaikan dan peningkatan kualitas hidup masyarakat.

\section{DAFTAR PUSTAKA}

Badan Pusat Statistik (BPS) Provinsi Kalimantan Tengah tahun 2014

Borg, W.R. \& Gall, M.D. (1979). Educational research, an introduction. 3 ed. New York: Longman

Kementerian Pendidikan dan Kebudayaan, 2015. Peraturan Menteri Pendidikan dan Kebudayaan Republik Indonesia Nomor
42 tahun 2015 tentang Penyelenggaraan pendidikan keaksaraan lanjutan, Jakarta: Direktorat Pembinaan Pendidikan Keaksaraan dan kesetaraan.

Permendikbud No. 4 Tahun 2015 tentang Ekuivalensi kegiatan pembelajaran

Pusat Data dan Statistik Pendidikan Kementerian Pendidikan dan Kebudayaan pada tahun 2014 